\title{
Analysis of Cirebon City Economic Growth for Public Development of Community Development
}

\author{
By: \\ Syaeful Bakhri ${ }^{11}$ \& Pahrul Fauzi ${ }^{2)}$ \\ ${ }^{1)}$ Faculty of Sharia and Islamic Economics, State Islamic Institute of Sheikh Nurjati Cirebon \\ ${ }^{2)}$ Faculty of Economics and Business, Wijayakusuma University Purwokerto \\ ${ }^{1)}$ Email: syaefulbakhrioke@gmail.com
}

\begin{abstract}
The purpose of this study is to analyze trends in the economic growth sector in the city of Cirebon. The type of research used is a type of research with a quantitative approach. The location of this research was conducted in Cirebon City. Data obtained for this study were obtained from the results of literature studies and documentation techniques. Secondary data such as data from the Central Bureau of Statistics of Cirebon City are the main data used in this study. The data analysis technique used in the study of the economic growth of Cirebon City uses several stages such as identifying the driving factors and inhibitors of economic growth in the City of Cirebon through the location quotient analysis tool and the leading sector. The majority of economic sectors in Cirebon City are classified as the base or superior sectors, which are detected from the value of $L Q$ statistic $>1$. However, not all of these base sectors experience progress or positive developments. There are only three sectors (social health service, communication information, and company service) that are classified as the base sector and have positive dynamics and growth.
\end{abstract}

Keywords: Economic Growth, Leading Sector, Cirebon.

\begin{abstract}
ABSTRAK
Tujuan dari penelitian ini adalah untuk menganalisis tren sektor pertumbuhan ekonomi di kota Cirebon. Jenis penelitian yang digunakan adalah jenis penelitian dengan pendekatan kuantitatif. Lokasi penelitian ini dilakukan di Kota Cirebon. Data yang diperoleh untuk penelitian ini diperoleh dari hasil studi literatur dan teknik dokumentasi. Data sekunder seperti data dari Badan Pusat Statistik Kota Cirebon adalah data utama yang digunakan dalam penelitian ini. Teknik analisis data yang digunakan dalam studi pertumbuhan ekonomi Kota Cirebon menggunakan beberapa tahapan seperti mengidentifikasi faktor pendorong dan penghambat pertumbuhan ekonomi di Kota Cirebon melalui alat analisis location quotient dan sektor unggulan. Mayoritas sektor ekonomi di Kota Cirebon diklasifikasikan sebagai sektor basis atau unggulan, yang terdeteksi dari nilai LQ statistik > 1. Namun, tidak semua sektor dasar ini mengalami kemajuan atau perkembangan positif. Hanya ada tiga sektor (layanan kesehatan sosial, informasi komunikasi, dan layanan perusahaan) yang diklasifikasikan sebagai sektor basis dan memiliki dinamika dan pertumbuhan positif.
\end{abstract}

Kata kunci: Pertumbuhan Ekonomi, Sektor Unggulan, Cirebon.

\section{INTRODUCTION}

Economic growth is the process of changing the condition of a region on an ongoing basis towards a better condition over a period of time which is at the same time the main indication in the economic development of a region. With the number and percentage of the urban population that is getting bigger and denser, it will certainly add to the increasingly heavy "living burden" of urban areas, giving 
rise to increasingly complex problems in the socio-economic, socio-cultural, political-government, order and security, etc. Among the various problems that stand out are those relating to urban poverty which includes conditions, characteristics, environmental facilities policies, and other related aspects.

Based on World Bank research (2003) there are six dimensions of poverty in urban areas in Indonesia, namely: 1) Ownership of assets and access to land is very difficult and limited; 2) Illegal housing conditions that are full of risks; 3 ) Low family population level and high level of life dependency; 4) The environmental conditions that birds have with the level of risk of exposure to the disease and the low access to health services that are low/ difficult/unreachable; 5) Job status is uncertain and unemployment is still high, and 6). The low accessibility of the community to urban basic facilities. Based on this, the problem of poverty in urban areas has its own characteristics that require different solutions and treatments.

The issue of inequality also colored the development process in West Java Province through a comparison of western and eastern regions, as well as districts/cities as autonomous regions. Development disparities are also experienced by regions that have just experienced expansion. In the following table, it is known that the average Gini index value in urban and rural areas (districts) in West Java Province from 2011 to 2016.

Table 1. Average Gini Index of Cities and Districts in West Java Province From 2011 to 2016

\begin{tabular}{ccc}
\hline Year & City & Regency \\
\hline 2011 & 0,37 & 0,30 \\
2012 & 0,40 & 0,33 \\
2013 & 0,40 & 0,33 \\
2014 & 0,38 & 0,31 \\
2015 & 0,43 & 0,34 \\
2016 & 0,41 & 0,35 \\
\hline
\end{tabular}

Source: Central Bureau of Statistics of West Java Province, 2017 (Processed)

Through Table 1, it can be seen in general that the level of inequality in urban areas is higher. In addition, growth in the level of inequality that occurs in urban areas is also relatively faster even though it is supported by a high level of economic growth. This condition is a contradiction in how economic growth in urban areas is not and is able to improve welfare that is evenly distributed among the people reflected through the Gini Index indicator.

\section{METHODS}

This type of research is a type of research with a mixed approach, mixed approaches, namely an approach which incorporates various methods, philosophies, and research design orientation by collecting and analyzing qualitative and quantitative data in a persuasive and rigorous manner (Indrawan and Yaniawati, 2014) The author conducts research on the problems that exist in the location by analyzing the data through statistical calculations. The location of this research was conducted in Cirebon City. Data obtained for this study were obtained from the results of literature studies and documentation techniques. Secondary data is the main data used in this study. The main secondary data sources needed in this study were obtained from the authorized institutions in providing data, namely the Cirebon City Central Statistics Agency (BPS). The supporting data as supporting research can also be obtained from the relevant agencies or agencies such as the Office of Industry and Trade of Cirebon City, Development Planning Agency at Sub-National Level of Cirebon and several other agencies or institutions needed.

The data analysis technique used in the study of the economic growth of Cirebon City uses several stages. Stages in calculating growth carried out two stages of analysis such as calculating the expected value of GRDP in Cirebon City. This is done by formulating the GDP trend, where the general equation of calculation is with the linear model. The next step is calculating the estimated economic growth of Cirebon City after the GRDP expectation value is found. 
After analyzing the economic growth of the city of Cirebon, the next technique is to identify the driving factors and inhibitors of economic growth in the city of Cirebon. In this study, the leading economic sector is an important study because it will determine the direction of economic growth whether to meet the target or below the target. To obtain identification of superior economic sectors, Location Quotient methods are needed in this growth study. To identify the superior sub-sectors or economic bases in the city of Cirebon with reference to West Java Province, Location Quotient analysis tools are used.

The measurement of the leading sector and economic growth in this study aims to detect the performance of each economic sector. The economic sector is said to be the most important sector in one region if its economic share tends to be higher than the share of other economic sectors. On the other hand, economic development in one sector is said to be better if the economic growth of the sector shows a magnitude of positive value and more relatively higher than the growth of other economic sectors. Thus, the economic sector is identified as having good performance if it is classified as having a higher share of the economy and growth compared to other economic sectors.

\section{RESULTS AND DISCUSSION}

\section{Cirebon City Economic Growth Analysis}

The city of Cirebon as one of the cities which is the axis of economic activity in the northern part of West Java, certainly cannot be separated from the problem of inequality. Quality economic growth needs to be sought in order to overcome the problem of inequality. Based on the results of the study of the Cirebon City Communication and Information and Statistics (DKIS) Office in 2017, it is known that the economic predictions of Cirebon City in 2018 and 2019 have decreased slightly (see Figure 1).

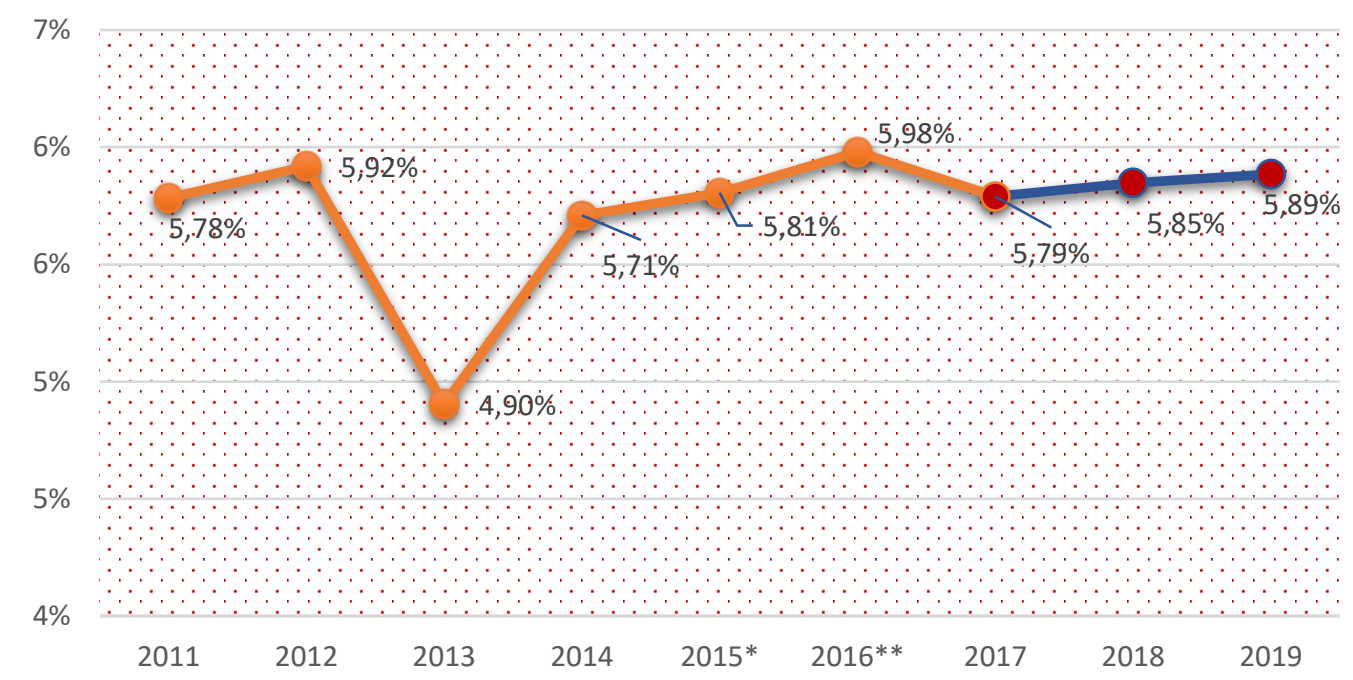

Figure 1. Estimated Economic Growth of Cirebon City 2018-2019 Source: Central Bureau of Statistics of West Java Province, 2018 (Processed)

Analysis of growth projections in the city of Cirebon can be used as a consideration for policymakers to be more directed and effective. Graph1 tries to present the development of the economic growth of Cirebon City from 2011 to 2016 and its expectations from 2017 to 2019. Economic growth in 2016 was around 5.98\%. Higher than in previous years. However, in 2017 there was a slight decline in economic growth to $5.79 \%$ (Cirebon City BPS, 2018). Based on the results of the analysis, the prediction of the condition of the economic growth of Cirebon City in 2018 and 2019 will return to positive growth. The inauguration of West Java International Airport Kertajati in Majalengka Regency in 2018 and infrastructure improvements are expected to contribute positively to the economy of Cirebon City. 


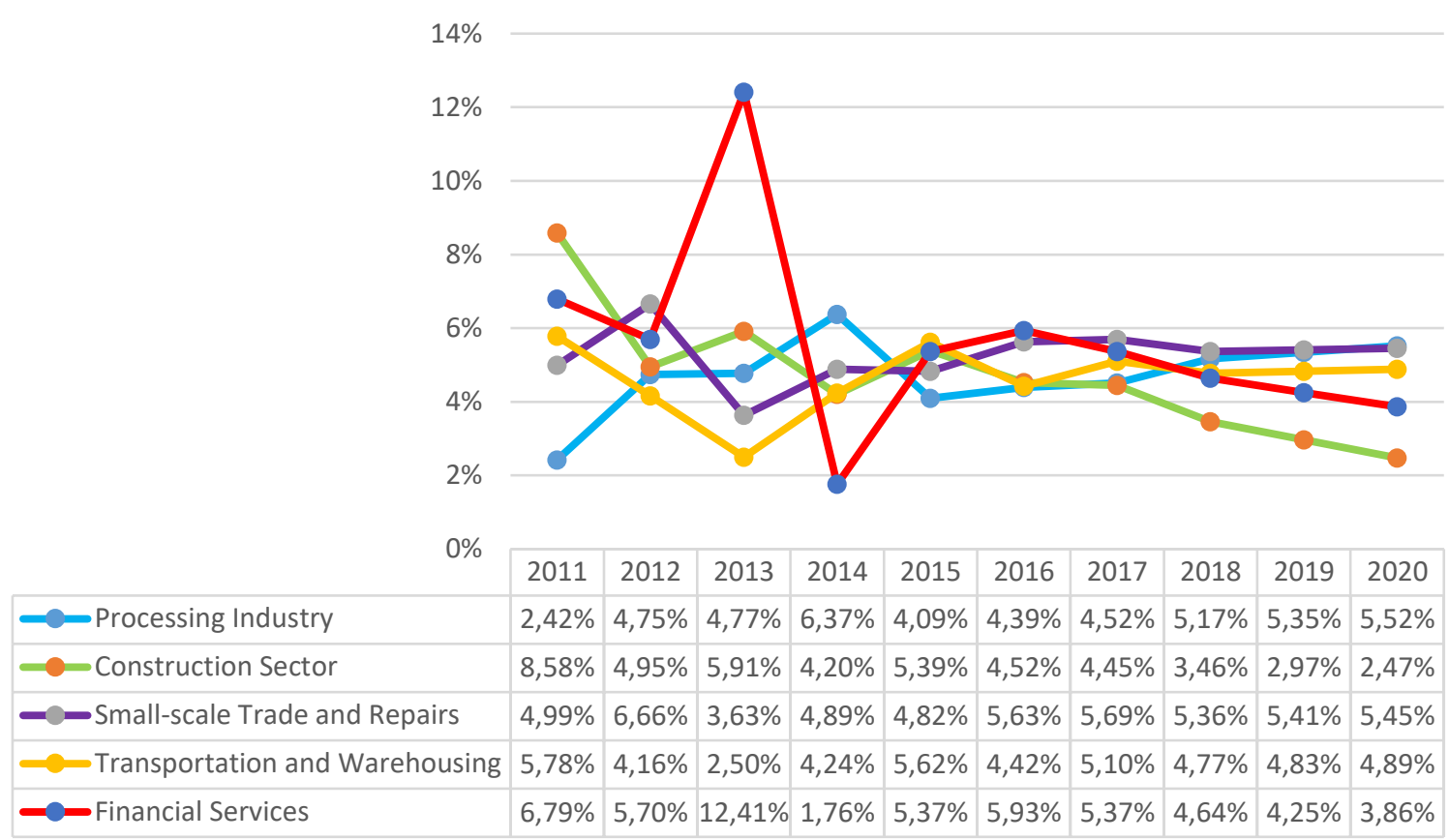

Figure 2. Estimated Economic Growth in 2018-2025 of Dominant Sectors in Cirebon City Source: Central Bureau of Statistics of Cirebon City, 2017 (Processed)

Based on Figure 2, Cirebon City is supported by 5 economic sectors which are the main contributors to the economy, namely the processing industry, construction sector, small-scale trade sector and motorcycle car repair, transportation and warehousing, and the financial services sector. The growth of the five economic sectors is the main driver of economic activity in the city of Cirebon. The processing industry sector is expected to experience positive growth given the economic development in Cirebon City which has continued to stretch in recent years. Even though in 2011 the growth was only around $2.42 \%$, growth that continued to increase from 2015 to 2017 provided a positive picture in the future that this economic sector will continue to grow better. This condition is similar to the trade and repair sector. There has been an improvement in growth from 2015 to 2016 which gives hope that this sector will grow higher in the following years.

The economic sector which is predicted to decline from the five main sectors is the construction sector and financial/insurance services. The construction sector shows a marked decline in growth. In 2011 this sector grew 8.58\%, in the following year only grew $4.95 \%$, in the last year developing this sector also experienced declining growth. The construction sector declined based on the number of lands in Cirebon City which began to decrease housing development. Other sectors are the financial services and insurance sectors which are also expected to decline in the coming years due to the influence of Indonesia's macroeconomic conditions which have caused public purchasing power to decline.

\section{Analysis of the Leading Economic Sector (Location Quotient)}

In mapping using the classification typology based on Central Bureau of Statistics publication data for GRDP based on constant prices in 2015, an overview of sectors that are leading sectors is obtained and shows positive dynamics is the social health services sector, the information communication sector and the corporate service sector. In addition to being an economic sector that is able to provide a positive multiplier effect on the economy as a whole, the three sectors are also detected to have a dynamic effect that shows the positive potential of developing the economic sector. 


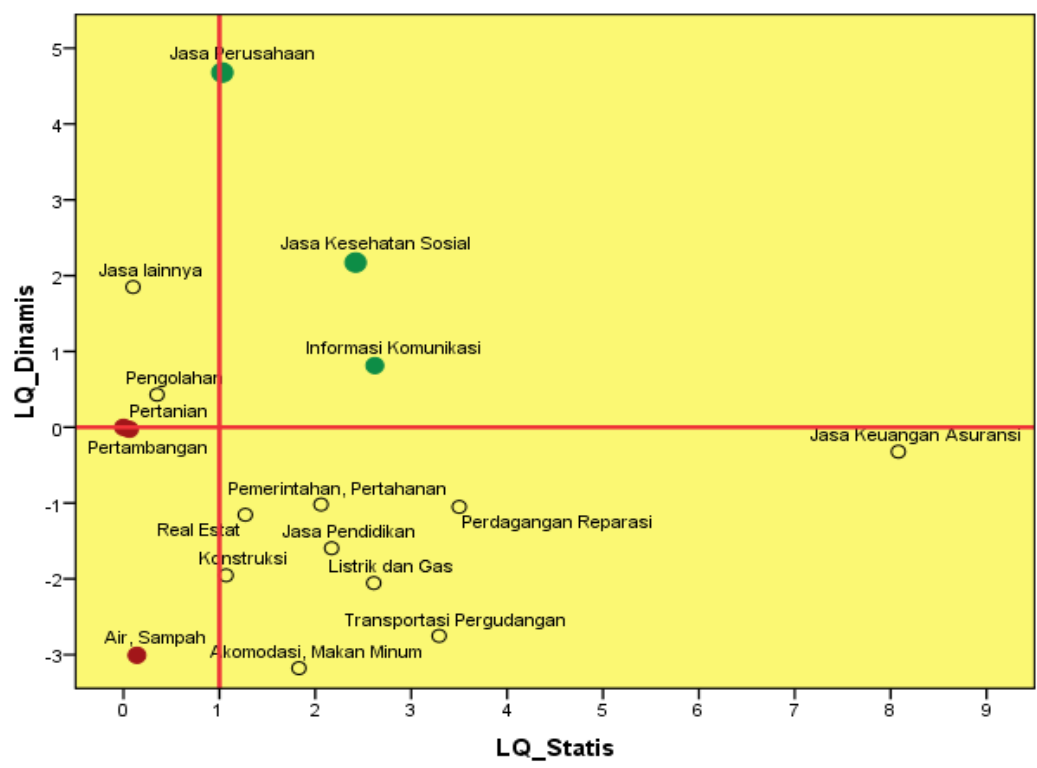

Figure 3. Cirebon City Featured Sector Map

Source: Central Bureau of Statistics of Cirebon City, 2016 (Processed)

The majority of economic sectors in Cirebon City are classified as the base or superior sectors, which are detected from the value of $L Q$ statistic $>1$. However, not all of these base sectors experience progress or positive developments. There are only three sectors (social health service sector, communication information, and company service sector) that are classified as the base sector and have positive dynamics. Nine other economic sectors belonging to the base sector were detected experiencing pressure as seen from the development of declining base values. This needs to be observed by the regional government because the slowing down of a base sector in the city of Cirebon shows that the same sector in other regions is indicated to have a stronger role in the overall economy. The base sector, however, was detected to be slowing down, among others, sectors: Large Trade and Retail; Car and Motorcycle Repair; Transportation and Warehousing; Provision of Accommodation and Drinking Meals; Electricity and gas procurement; Construction; Education Services; Real Estate; Financial and insurance services; and Government administration, Defense and Compulsory Social Security.

Mapping for the economic sector that has progressed but is not a leading sector, among others, the manufacturing industry and other service sectors. In this dimension (non-base but developing positively) it needs to get the attention of the Cirebon City regional government.

In the last classification, the sector experiencing setbacks is; a) Fisheries Forestry Sector and b) Water Supply Sector, Waste, Waste, and Recycling Management. For the agriculture sector, fisheries forestry, the decline of this sector is still relatively reasonable because of the position of Cirebon City which is not intended for businesses in the primary sector. However, the decline in the water supply sector, waste/ waste/recycling management needs to be in the spotlight for the progress of Cirebon City in the future.

\section{A contribution of Economic Sub Sector in GDP of Cirebon City}

In the city of Cirebon, the economic sector that dominates the regional economy is the service and manufacturing sectors as illustrated in graph4 below. This condition is reasonable considering that Cirebon City is an urban area. Theoretically, economic interactions in urban areas are dominated by modern economic sectors such as the service sector and manufacturing. Specifically, the economic sectors that dominate the city of Cirebon area. Large trade, retail, car and motorcycle repair sectors, b. The construction sector, c. Financial and insurance services sector, d. Transportation and warehousing sector, as well as e. Processing industry sector. 


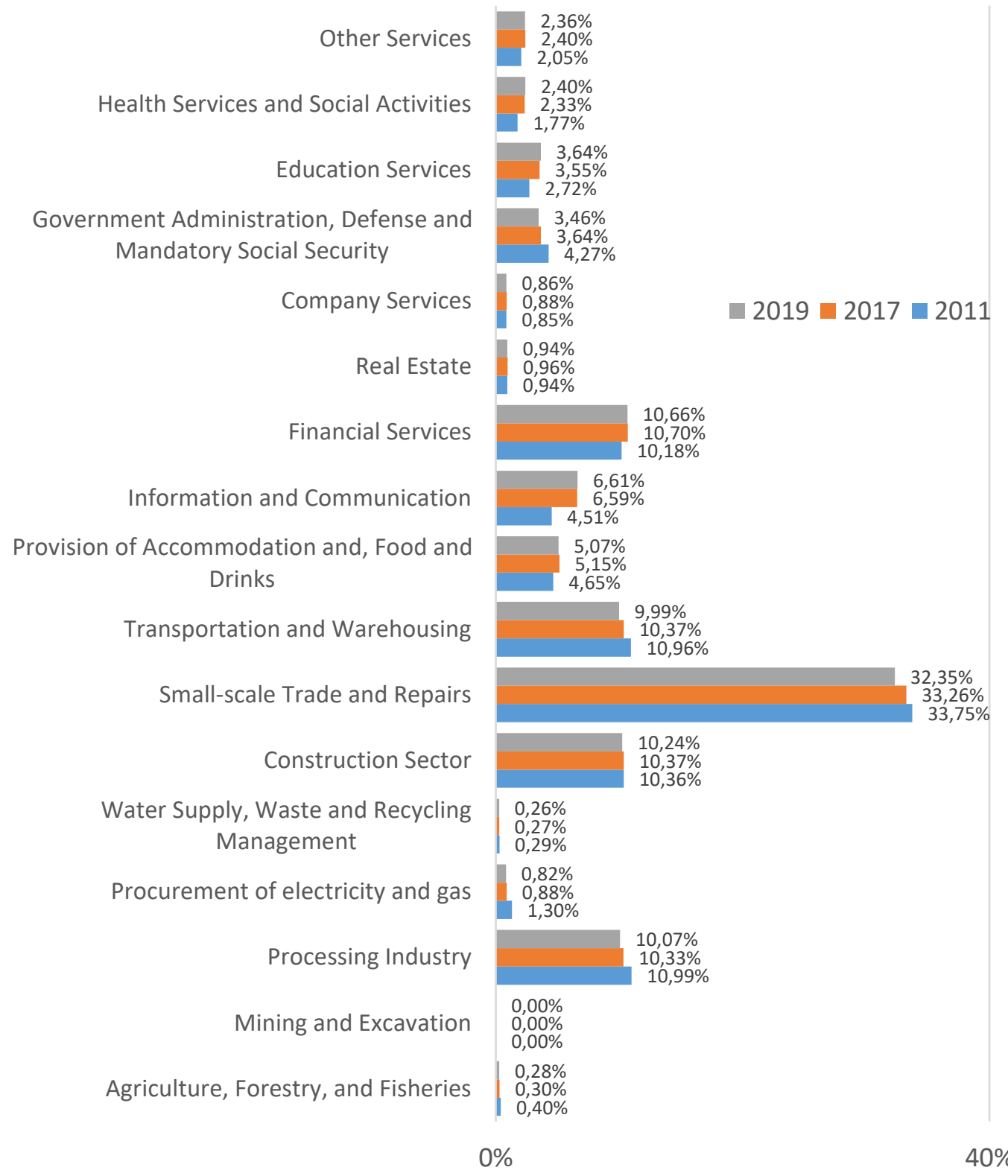

Figure 4. Contributions of the Cirebon City Economic Sectors in 2011, 2017, and Estimated 2019 Source: Central Bureau of Statistics of West Java Province, 2018 (Processed)

In 2011, the retail, car and motorcycle repair trade sector contributed around $33.75 \%$. However, this sector shows a declining trend. In the last data year, 2017, this sector contributed $33.26 \%$ and is expected to decline again in 2019 with a contribution of $32.35 \%$ of the total GDP of Cirebon City. The processing industry is also expected to experience a contribution of around $0.26 \%$ from 2017 to 2019. The transportation sector is also predicted to experience a contribution of $0.38 \%$ from 2017 to 2019 . While the construction and real estate sectors tend to contribute unchanged or relatively stable.

On the other hand, the economic sector which shows an increase in contribution to the economy of Cirebon City is the financial and insurance services sector. In 2011 this sector contributed $10.18 \%$ and is expected to increase by $0.48 \%$ in 2019 to $10.66 \%$. Other economic sectors that tend to provide increased contribution ratios in Cirebon City GRDP are health and social services by $0.63 \%$ from 2011 to 2019 , education services by $0.92 \%$, food and beverage accommodation providers up by $0.42 \%$, and sectors information and communication rose by $2.10 \%$ from 2011 to 2019 .

The dynamics of changes in sectoral contributions to the regional GDP is a dynamic economic activity of the community and also shows a tendency to shift the pattern of economic concentration 
towards an increasingly modern economic sector. The problem that arises and tends to be feared from the urban economic development from the shift towards the modern economy is the change in economic concentration from labor-intensive trends to capital-intensive tendencies. In addition, a common problem with the development of urban areas is the increasing problems related to the environment, water, and energy. This is also indicated in the city of Cirebon. The distribution of the contribution of the economic sector above shows a decline in the contribution of the water supply, waste and waste management sectors, which was also followed by a decrease in the procurement of electricity and gas. Environmental issues will be related to how the public sector is able to provide a decent and comfortable city space for residents who are protected from waste and waste problems. The public sector also needs to pay attention to providing clean water as an effort to improve the quality of people's health. Similarly, the supply of electricity and gas is vital in the running of the modern economy.

\section{Income Distribution in Cirebon City}

Visually (graph 5), Cirebon City over the span of the 2011 to 2016 period, BPS statistics show that the population growth of Cirebon City is a positive average of $0.81 \%$. The highest percentage of population growth in the last six years in the city of Cirebon was recorded in 2016 which reached $0.96 \%$.

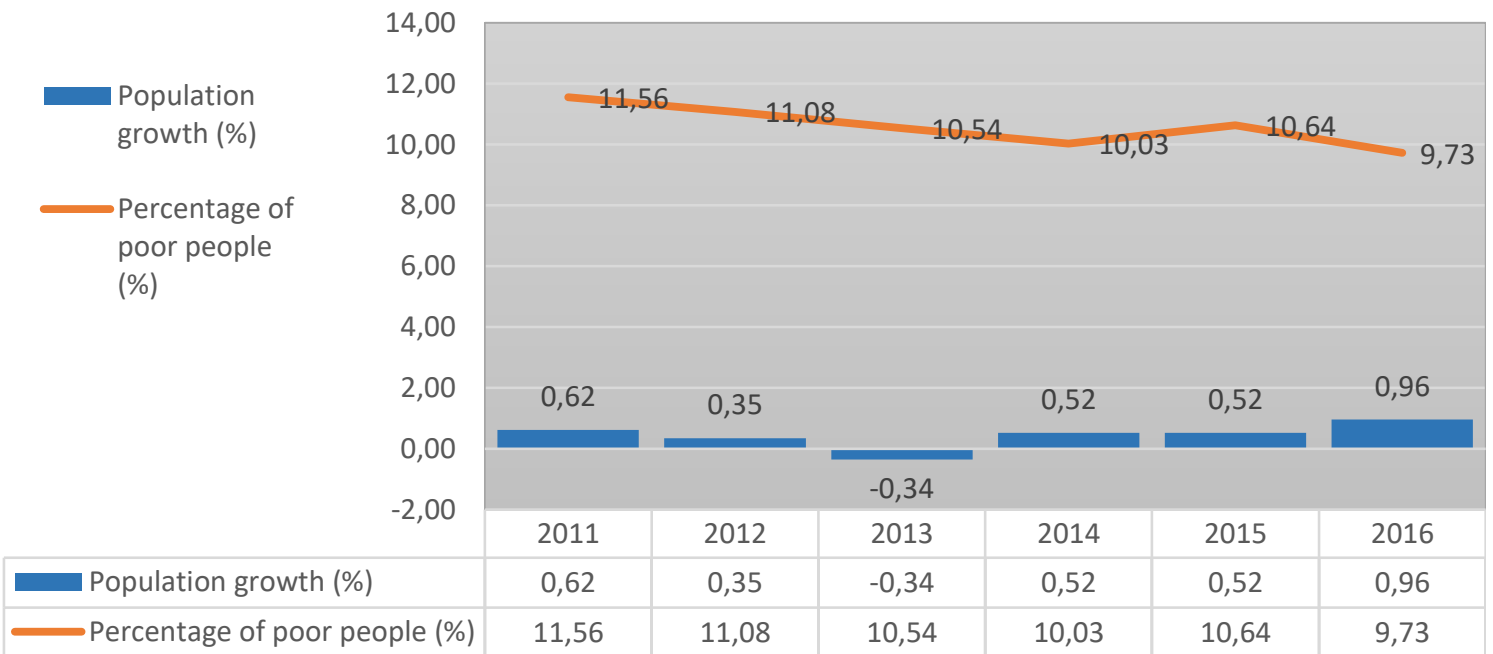

Figure 5. Population Growth and Proportion of Poor Population (\%) in Cirebon City from 2011 to 2016 Source: Central Bureau of Statistics of Cirebon City, 2017 (Processed)

On the other hand, population development in Cirebon City shows a positive direction in terms of poverty. The average number of poor people in Cirebon City from 2011 to 2016 was $10.4 \%$. The latest data year, the poverty rate of Cirebon City in 2016 reached $9.73 \%$. If it is linked between population growth and the proportion of poverty, there is an identification of reduced poverty but must be accompanied by a reduced population. Statistical calculations show the positive correlation value of the changes in the two variables is 0.355 ( $p$-value $=0.388$ ). The problem of the still high level of poverty in the city of Cirebon also coincides with the still quite high aspects of income inequality.

In the last year of 2016, the Gini index value was 0.40 . This condition improved from the previous year which reached 0.41 . However, the level of equity in 2011 was still better than the condition in 2016. The Gini index in 2011 amounted to 0.38. By including the Gini index as a proxy for the level of income distribution with various other variables, it can be made a mapping with Klassen's typology on the relative position of Cirebon City with other regions in West Java. The first typology is between the Gini index (with an average area in West Java of 0.367) and the proportion of poor people (with an average area in West Java of 9,436). The results of preliminary identification of the typology between the Gini index and the proportion of poor people indicate the position of the city of Cirebon at a position where the level of income is low and the proportion of poor people is high. 
0,45

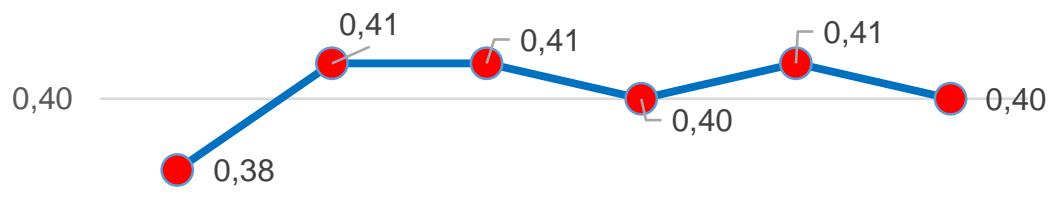

0,35

$20112012 \quad 2013 \quad 2014 \quad 2015 \quad 2016$

Figure 6. Development of Cirebon City Gini Index in 2011-2016

Source: Central Bureau of Statistics of West Java Province, 2018

From the results of the analysis, the variables identified as having an important impact are population, economic growth, and classification of administrative forms. The variable population number provides a positive direction which indicates that the increasing number of people in the provinces of West Java will tend to increase income inequality. Population planning as an effort to prevent population explosion will have a positive potential for income distribution.

The second important variable is economic growth which has a positive effect on income inequality. The higher economic growth will encourage increased inequality. From these results, a more in-depth study is needed on why in the case of areas in West Java there is a positive effect of economic growth on people's income inequality.

The third important variable is the form of regional administration. The dummy variable in the city district places the administrative index by giving a value of 1 for the city area and 0 for the district area. The results of the analysis show that the coefficients are positive and statistically significant. This result identifies that districts in the form of districts tend to have better income distributions than cities.

Table 2. Effect of Regional Macroeconomic Conditions on Income Inequality in the Region of West Java

\begin{tabular}{lccc}
\multicolumn{4}{c}{ Province } \\
\hline Constant and Variable & Coefficient & t Statistic & Probability Error \\
\hline Constant & 0.203 & 5,167 & 0,000 \\
GDP (IDR billion) billion & $-5,127 \mathrm{E}-7$ & $-1,627$ & 0,119 \\
Population (thousand people) & $1,939 \mathrm{E}-5$ & 2,201 & 0,040 \\
Economic growth (\%) & 1,562 & 4,123 & 0,001 \\
Per capita income (Rp) & $1,144 \mathrm{E}-9$ & 1,499 & 0,150 \\
Poor Population (\%) & 0,002 & 0,810 & 0,427 \\
D (Dummy: city = 1, village = 0) & 0,059 & 0,565 & 0,000 \\
\hline Ad.
\end{tabular}

Adj. $R^{2}=0.723, F=12.333, D W=1.422$

Source: Primary Data Processed, 2018

On the issue of the effects of economic growth in the West Java region, especially in the city of Cirebon, the results of statistics show economic growth pushed up the income gap. This gives an indication that cities in West Java Province are still in the phase of industrialization. A further problem is when economic growth can encourage income equity. If growth is still a central focus without other efforts to create employment, public facilities services that reach all income groups or classes and encourage improvements in the urban environment, cities in West Java will always face problems of income inequality.

There are several efforts that can be recommended to reduce the level of income inequality in urban areas, in this case, Cirebon City, although efforts to encourage economic growth are also other economic development goals that still need to be pursued. Policies that can be taken can be categorized into two, theoretically and thematically. Theoretically here is intended to be a policy to 
encourage the distribution of income that has been studied in various theoretical references. Meanwhile, thematic policies are intended policies that need to be carried out specifically based on specific locations. In the case of efforts to reduce economic inequality in the city of Cirebon, theoretical policies will still need to be important considerations because the efforts put forward in this approach have become public studies and proven in many places.

In an effort to encourage income distribution, theoretically it can be done through (a) Increasing minimum wages, (b) Increasing progressive income tax (c) Making it easier for working families to have residential property (d) Investment in the education sector (e) Facilitating population mobility (f) Reducing the tension of conflict between population groups.

\section{Analysis of the Economic Gap of Cirebon City}

Some figures are explained regarding the poverty conditions in Cirebon City in 2015, 2016 and 2017 based on the publication of the West Java Province BPS in 2018. To find out the size of the average disparity in the expenditure of the poor on the poverty line, the poverty depth index (Poverty Gap Index = P1) is used. In 2015 the poverty depth index of Cirebon City reached 1.28 and increased in the following year to 1.86 but then fell back in 2017 to 1.56 . This is in line with the increasing poverty severity index in 2016 but fell again in the following year.

Table 3. Number of Poor Population, Percentage of Poor Population, Depth of Poverty Index, Poverty Severity Index, and Poverty Line in Cirebon City in 2015, 2016, and 2017

\begin{tabular}{lccc}
\hline \multirow{2}{*}{ Criteria } & \multicolumn{3}{c}{ Year } \\
\cline { 2 - 4 } & 2015 & 2016 & 2017 \\
\hline Number of poor population (in thousands) & 31,74 & 30,15 & 30,19 \\
Percentage of poor population & 10,36 & 9,73 & 9,66 \\
Poverty depth index & 1,28 & 1,86 & 1,56 \\
Poverty severity index & 0,26 & 0,49 & 0,43 \\
Poverty line (Rp / capita / month) & 358.654 & 373.866 & 392.725 \\
\hline
\end{tabular}

Source: Central Bureau of Statistics of West Java Province, 2018 (Processed)

The description of the distribution of expenditures on the poor to the poverty line can be known through the poverty severity index. The poverty severity index in Cirebon City in 2015 reached 0.26 which then increased to 0.49 in 2016 and again declined in 2017 to 0.43 . The depth and severity index of poverty in Cirebon City in the last three years has been volatile.

Of course, efforts to alleviate the problem of poverty need to be sought by all parties not only by the government. Moreover, based on the previous analysis it can be seen that the problem of poverty in urban areas, including in the city of Cirebon, has its own characteristics. One of the real efforts to alleviate the problem of poverty in urban areas is to minimize the gap in both the inequality of income and inequality of opportunity for people in urban areas, (2017 Literature).

\section{CONCLUSION}

Based on the results of the analysis, some conclusions can be found as follows: 1) The economic growth of Cirebon City experienced a positive trend in the last three years. Even in three years, it was able to surpass the average growth rates of West Java and National levels. Even so, the economic growth of Cirebon City still has a weak correlation with the reduction in poverty rates and equitable development. 2) When looking at the analysis of the economic structure, Cirebon City needs to carry out policies to optimize the leading sectors that have potential growth so that they can be used as a driving force for the economy while being able to absorb labor and reduce the percentage of poor people. 3) Comparative analysis with other regions in West Java shows that Cirebon City has a fairly good position in terms of economic growth and the human development index (HDI), but Cirebon City needs to pay attention to aspects of income distribution and the still high percentage of poor people. 4) No less important than the three points of the conclusion above, the development planning of Cirebon City, 
especially in the economic field, really needs to be supported by the quantity and quality of data. Through the availability of data, especially sectoral data in the economic field, economic development planning in the city of Cirebon can be done more thoroughly, effectively, and directed.

\section{REFERENCES}

Central Bureau of Statistics of Cirebon City. (2017). Central Bureau of Statistics of Cirebon City in Figures. Cirebon, Indonesia: Central Bureau of Statistics of Cirebon City.

(2017). GDP of Cirebon City. Cirebon, Indonesia: Central Bureau of Statistics of Cirebon City.

Indrawan, R. \& Yaniawati, P. (2014). Quantitative, qualitative, and mixed research methodology for management, development, and education (first edition). Bandung, Indonesia: PT. Refika Aditama.

Jhingan, M. L. (2000). Economic development and planning (eight edition). Jakarta, Indonesia: Grafindo Persada.

Kusuma, S., Palar S. W., \& Lapian, A. L. C. P. (2016). Analysis of economic structure and economic growth in Ternate City. Journal of Scientific Periodic Efficiency, 16(2), 515.

Lincoln, A. (1999). Introduction to regional economic development planning (first edition). Yogyakarta: BPFE.

Literature, E. (2017). Economic inequality: realizing social justice in Indonesia (first edition). Jakarta: PT. Mizan Publika.

Romi, S. \& Umiyati, E. (2018). Effects of economic growth and minimum wages on poverty in Jambi City. E-Journal of Economic and Regional Development Perspective, 7(1), 6.

Utomo, T. W. W. (2006). Prospects for the development of inter-regional cooperation in districts / cities in East Kalimantan in the implementation of development and community service affairs. Borneo Administrator Journal, 2, 84.

Wahyudi, A. (2017). Study of functions and role of city and district in economic affairs in the operation of metropolitan Cirebon. Journal of Plano Madani Regional and City Planning, 6, 44. 